Ненад Нинковић

Универзитет у Новом Саду

Филозофски факултет

докторанд

nenadninkovich@yahoo.com
Оригиналан научни рад

примљено: 30. април 2014

прихваћено: 1. октобар 2014

\title{
АДМИНИСТРИРАЊЕ КАРЛОВАЧКОМ МИТРОПОЛИЈОМ ЕПИСКОПА МОЈСИЈА ПУТНИКА *
}

Сажетак: Tempore sedis vacantis или седисваканција претставља латински израз који је употребљаван и у српској црквеној терминологији у Хабзбуршкој монархији како би се означио период током којег је нека епископска или митрополијска катедра упражњена. У раду се говори о три седисваканције, које су по времену трајања најдуже у другој половини XVIII века (1768-1769, 1773-1774. и 1780-1781) и Мојсију Путнику који је током њих управљао Српском црквом.

Кључне речи: Карловачка митрополија, седисваканција, администратор, Сабор, Јован Георгијевић, Вићентије Јовановић Видак, Мојсије Путник.

Седисваканција (tempore sedis vacantis) представља период током којег је један епископски или митрополијски трон Карловачке митрополије био без свог дијецезана. У српској средини у Хабзбуршкој монархији овај термин је ушао у употребу у додиру са државном администрацијом и имао је пандан у изразу удова епархија или удова митрополија, који се, такође, среће у документима и мемоарској литератури. Појам администратора и појам администрације једном дијецезом или црквеном организацијом у нераскидивој су вези са седисваканцијом, јер су администратори Карловачке митрополије били епископи који су црквом управљали док се не изабере нови митрополит. Седисваканција је трајала од смрти једног до избора и посвећења другог митрополита, док је администрација била нешто краћа, јер комуникација није дозвољавала да се истог дана, којег је првојерарх умро, постави администратор.

Прва седисваканција у српској цркви на подручју Хабзбуршке монархије почела је 7. новембра 1706. смрћу патријарха Арсенија III Црнојевића и трајала је све до избора митрополита Вићентија Поповића Хаџилавића 1713. Карловачка митрополија је била више под администраторством, него што је имала првојерарха, пошто су прва два митрополита, Исаија Ђаковић (1708) и Софроније Подгоричанин (1710-1711), провели на митрополијском трону по мање од годину дана, док су 
администрације трајала дуже од године. ${ }^{1}$ После ових уследиле су седисваканције које нису трајале дуже од осам месеци, ако се овде не рачуна она после смрти митрополита Вићентија Јовановића 1737. Наиме, неколико месеци (јун-новембар) администратори су били епископ темишварски Николај Димитријевић и бачки Висарион Павловић, а онда је то постао пећки патријарх Арсеније IV Јовановић Шакабента, који је предложен Двору за потврду као митрополит. До ње је прошло доста времена и иако је патријарх раније био прихваћен од стране епископата и Двора, то је формално учињено тек октобра 1741. Ипак, како је његов утицај био далеко већи од администраторовог, а било је извесно да ће уследити и формална потврда, не може бити речи о седисвакантном периоду у правом смислу те речи. Наредне две седисваканције - 1748. и 1749, биле су кратке: прва шест а друга пет месеци. По времену трајања њима се приближава последња седисваканција у XVIII веку (из 1790) која је била краћа од пет месеци. Између 1749. и 1790. трон карловачких митрополита је био упражњен три пута: после смрти митрополита Павла Ненадовића од 26. августа 1768. до 7. септембра 1769, када је изабран митрополит Јован Георгијевић, после чије смрти је седисваканција трајала од 23. маја 1773. до 10. јуна 1774. када је митрополит постао Вићентије Јовановић Видак и на крају од 29. фебруара 1780 . до 3. јула 1781. када је за митрополита изабран Мојсије Путник. ${ }^{2}$

Бачки епископи су били најчешћи администратори током XVIII века, чак осам пута, за шта је највероватнији разлог била близина митрополијског и њиховог епархијског седишта. ${ }^{3}$ Ово није било неко утврђено правило, нарочито од када је Двор почео да намеће свој утицај приликом постављања администратора, те су удовом Митрополијом управљали у поменутом веку још: митрополит сремски Стефан Метохијац, пакрачки владика Софроније Подгоричанин, арадски Исаија Антоновић, вршачко-карансебешки Јован Георгијевић и четири пута темишварски дијецезани, Николај Димитријевић, Мојсије Путник и Петар Петровић. Дешавало се и да се током једне седисваканције смени више администратора или да заједно управљају Митрополијом. Уз митрополита Стефана Метохијца извесно је утицао на живот цркве Исаија Ђаковић, а током наредне седисваканције, после Метохијчеве смрти (1709), морао се поставити нов администратор. ${ }^{4}$ Оваква ситуација се

\footnotetext{
* Текст је настао као фазни резултат рада на пројекту Војвођански простор у контексту европске историје (број 177002) Министарства просвете, науке и технолошког развоја Републике Србије.

${ }^{1}$ После смрти патријарха Арсенија III трон је био упражњен од 7. новембра 1706. до 8. јануара 1708, тј. пуних 14 месеци, после мирополита Исаије Ђаковића седисваканција је трајала 19 месеци (1708-1710), а после митрополита Софронија Подгоричанина чак 28 месеци (1711-1713). Димитрије Руварац, Ко је постављао администраторе Митрополије Карловачке од 1707.-1712.?, Архив за историју Српске православне митрополије карловачке, 1, Сремски Карловци 1912, 36-37.

2 Исто, 33-48; Ненад Нинковић, Црквено-народни сабор и Архијерејски синод из 1749. године, Истраживања, 23, Нови Сад 2012, 261-265; Исти, Исаија Антоновић епископ арадски и митрополит карловачки (1731-1749), Истраживања, 24, Нови Сад 2013, 193-195.

${ }_{3}^{3}$ Митрополит Стефан Метохијац је други пут администрирао Митрополијом као бачки дијецезан (до смрти 1709), затим су из ове епархије администрирали још: Христофор Димитријевић (до смрти 1712), Софроније Томашевић, Висарион Павловић (чак три пута) и Мојсије Путник, који је два пута администрирао као бачки епископ а једном као темишварски.

${ }^{4}$ Славко Гавриловић, Исаија Баковић, архимандрит гргетешки, епископ јенопољски и митрополит
} 
поновила после смрти владике и администратора Христофора Димитријевића (1712). Експоненти супарничких страна су паралелно администрирали Митрополијом, ${ }^{5}$ а било је и одбијања Двора да неког прихвати за администратора.

Између осталих седисваканција и администрација из XVIII века оне које су биле у периоду 1768-1769, 1773-1774. и 1780-1781. одвијале су се у сенци државних реформи чијим завршетком је у великој мери измењен целокупни друштвени живот и Срба у Хабзбуршкој монархији. Од 1768. до 1781. извршене су прва и друга редукција заповедних празника у календару који је важио у Карловачкој митрополији, донети су Први и Други регуламент и Деклараторија, Јозеф Курцбек је добио право штампања ћирилских књига, састављен је Катихизис, реформисано школство, укинита Илирска дворска депутација и 1782. донета Конзисторијална система. Дубина и значај ових промена осетили су се и у време седисваканције, током које је и Двор изграђивао свој став о томе ко би био пожељан за митрополита, како би ове реформе, суштински инициране или наметане са његове стране, биле лакше прихваћене и спроведене. При томе се, са данашње дистанце, не може говорити да су све међу њима биле негативне, нарочито не оне које су се тицале календара и реформе школа. Администратори су током управљања митрополијом имали пре свега једну важну обавезу, да припреме народно-црквени сабор који би изабрао новог митрополита. Међутим, у пракси се показало да су за њих, уз овај посао, веома важна финансијска питања која су покушавали да реше у скученим оквирима Регуламената и Деклараторије, а у складу са интересима народа и властитим амбицијама.

Седисваканција 1768-1769. После дугог боловања и пуних 19. година управљања Карловачком митрополијом, што је до тада био најдужи стаж једног првојерарха ове цркве, 26. августа 1768. у два сата после поноћи умро је митрополит Павле Ненадовић. Управу црквом су одмах преузела двојица епископа која су у тренутку митрополитове смрти била у седишту Митрополије, бачки Мојсије Путник и темишварски Вићентије Јовановић Видак. Они су и обавестили вернике и епископе о смрти митрополита и организовали све што је било потребно за његову сахрану. После парастоса који је служен 21. септембра састали су се у Карловцима народни прваци са епископима: вршачким Јованом (Георгијевићем), бачким Мојсијем, темишварским Вићентијем и пакрачким Арсенијем (Радивојевићем). Том приликом је одлучено да бачки дијецезан преузме администрацију над удовом Митрополијом, а уз то да се тражи скидање забране (шперта) са Даљског властелинства и Нерадина, како би се приходи од ових поседа искористили на добробит народа, али једном стављена она није могла бити скинута. Такође, решили

\footnotetext{
крушедолски, Зборник Матице српске за историју, 74, Нови Сад 2006, 18-28.

5 Пример за ово је седисваканција после смрти митрополита Вићентија Јовановића 1737. Двор је за администратора прихватио дотадашњег митрополијског коадјутора, темишварског владику Николаја Димитријевића, али је народ и епископат на то место поставио бачког владику Висариона Павловића. Њих двојица су тако фактички администрирали заједно до доласка, исте године, патријарха Арсенија IV у Хабзбуршку монархију, када је он преузео администрацију. Тако је током ове седисваканције било три администратора. Милутин Јакшић, О Арсенију IV Јовановићу Шакабенти, Карловци 1899, 2-25; Исти, O Вићентију Јовановићу, Нови Сад 1900, 165-167.
} 
су да траже од владарке да наредни сабор, који је заказан као расправни, још за живота Павла Ненадовића, добије карактер и изборног. ${ }^{6}$

Владика Мојсије Путник је био међу најобразованијим Србима свог доба, са завидним животним искуством, нарочито у односима са Двором и другим конфесијама, близак претходном митрополиту и свакако један од најутицајнијих епископа. ${ }^{7}$ Двор против њега није имао ништа, али је избор администратора сматрао искључиво својим правом, што је озваничено још 19. априла 1749 , када је на предлог грофа Фердинанда фон Коловрата, председника Илирске дворске депутације, донето решење по којем је постављање администратора Карловачке митрополије искључиво регално право владара. Приликом израде саборског устројства, на Сабору из 1749. на основу праксе и акта који је на претходном Сабору дао комесар Франц Леополд фон Енгелсхофен покушали су посланици да наметну решење по којем би администратора постављао народ, међутим, коначан текст саборског устројства ову одлуку не садржи, што је била последица утицаја комесара из 1749 , генерала грофа Христијана фон Хелфрајха. ${ }^{8}$

У периоду до 1749. Двор је најчешће потврђивао предложеног администратора, али је овог пута намеравао да покаже своје право. Већ 3. октобра 1768. царски комесар гроф Андраш Хадик је јавио владици Путнику да преко шесточлане делегације морају тражити дозволу да се на Сабору бира и митрополит, али и да је администрација предата вршачком епископу Јовану, док су њему остављене две седисвакантне епархије: Будимска и Арадска, које су упражњене крајем 1767. и у марту $1768 .^{9}$ Овај потез је сматран наклоношћу Двора, јер су настојали да владици Мојсију на неки начин надокнаде изгубљену администрацију Митрополијом. Он је неколико дана касније одговорио на ово писмо захваљујући се што му је скинуто бреме тешког посла и одговорности. Указао је на то да је владика Јован администрацију добио због своје старости (био је по хиротонији најстарији епископ Карловачке митрополије) и беседе коју је изговорио на митрополитовом парастосу у Карловцима, ${ }^{10}$ мада је значајнија чињеница да је истог дана после парастоса на састанку са народним првацима вршачки епископ водио главну реч. ${ }^{11}$

\footnotetext{
${ }^{6}$ Архив Српске академије наука и уметности - Сремски Карловци (даље: АСАНУК), МПА „А“ 133, 136, 137, 139, 142, 147. и 149/1768.

${ }^{7}$ Мојсије Путник је рођен у Новом Саду 1728. Школовао се у Карловцима и Кијеву, где је завршио Духовну академију. Замонашио се у Раковцу, а митрополит Павле Ненадовић га је рукоположио најпре за протосинђела, затим архимандрита, постављајући га за свог егзарха, и на крају 1757. за епископа бачког. Био је митрополијски егзарх у Арадској епархији у комисији која је одвајала православне од унијата. Доста пажње је посвећивао образовању свештенства и народа, па је сам издржавао богословску школу, а настојао је и да отвори Семинарију. До 1775. је био бачки владика, а потом шест година темишварски, док 1781. није постао митрополит. Умро је у Бечу 1790, а сахрањен је у Сентандрејској саборној цркви.

${ }^{8}$ Н. Нинковић, Црквено-народни сабор..., 264-265.

${ }^{9}$ АСАНУК, МПА „А“ 151,159 . и 160/1768. Будимском епископијом је као администратор још од смрти владике Дионисија управљао шишатовачки архимандрит Вићентије Поповић, док је Арадском администрирао Петар Петровић. АСАНУК, МПА „А“ 26, 30-32. и 162/1768.

${ }^{10}$ АСАНУК, МПА „А“ 150 . и 161/1768.

${ }^{11}$ Састанку су присуствовали епископи: вршачки Јован, бачки Мојсије (који је заступао горњокарловачког Данила и костајничког Јосифа), темишварски Вићентије и пакрачки Арсеније Радивојевић, архимандрити: шишатовачки Вићентије Поповић и крушедолски Пахомије, беочински игуман Синесије, карловачки протопрезвитер Јефтимије и новосадски Андреј, обрствахтмајстер Николић, новосадски
} 
Вративши се у Нови Сад, Мојсије Путник је обавестио посебним писмом новог администратора о свему што је урадио од митрополитове смрти, нарочито о стављању судске забране на поседе Даљ и Нерадин. ${ }^{12}$

Први регуламент је прописивао да администратор током седисваканције за сваки дан своје управе Митрополијом добија 24 форинте. ${ }^{13}$ Овај новац је требало да буде употребљен за издржавање кухиње, коња, послуге и угошћавање странаца. ${ }^{14}$ Владика Георгијевић је покушао да дође до још неких финансијских средстава, јер су приходи митрополита били већи у редовном стању, када су поред онога што су убирали у Архидијецези добијали еквивалент десетка, кнежевске дукате, поклоне и приходе од Даљског властелинства и Нерадина. ${ }^{15}$ Администратори су морали да воде цркву без ових средстава, што није било лако, те је владика Јован молио да му се бар исплати део кнежевских дуката, јер последња рата није предата митрополиту Павлу Ненадовићу, него се још налазила у Камералној каси у Темишвару. Како је у неколико наврата молио и да са Даљског поседа буде скинута забрана, Илирска дворска депутација је почетком октобра 1768. јавила администратору да судске забране остају за све поседе на снази, односно да у погледу Арадске и Будимске дијецезе може до даљњег рачунати на status quo (у смислу финансијских потраживања). ${ }^{16}$

Током октобра 1768. Јован Георгијевић је напустио Карловце, а његова активност као администратора се на основу расположивих докумената не види све до фебруара $1769 .{ }^{17}$ Непознато је који су га разлози на ово навели, није искључено да су у питању били финансијски, али су у сваком случају Двор и Илирска дворска депутација у то време чешће комуницирали са бачким владиком. Он је поштујући

биров Рацковић, формунтери Павловић и Дима Костић, сенатор Потиског дистрикта Загоричанин, карловачки штатрихтер Матић и постфелвалтер Андрејевић. АСАНУК, МПА „А“ 142/1768.

${ }_{12}^{12}$ АСАНУК, МПА „А“

${ }^{13}$ Ова средства нису била мала, јер су на годишњем нивоу износила око 8.760 форинти, док је нпр. митрополијски еквивалент десетка износио 9.000 форинти.

${ }_{14}^{14}$ Архив Српске академије наука и уметности (даље: АСАНУ), 7253.

15 Даљско властелинство, које се састојало од насеља Бело Брдо, Борово и Даљ, било је трећи посед који је патријарх Арсеније III добио од Двора 1706 (пре њега је краће време уживао посед Сирач, а потом Сечуј), на име дуговања које је имао према њему у износу од 38.675 форинти. Посед му није дат као наследно него уписно добро, које је услед смрти првојерарха, у време седисваканције, враћано у руке Дворске коморе, а препуштано опет новом митрополиту по његовом увођењу у трон. Овако устаљена пракса је прекршена већ 1726. када је услед спајања Београдске и Карловачке митрополије посед до 1729 остао у рукама Коморе. Такође, у њеним рукама је био од смрти митрополита Вићентија Јовановића (1737) до званичне потврде патријарха Арсенија IV (1741). Иако су народно-црквени сабори упућивали захтев да Даљско властелинство постане наследно добро, то се до 1868. није десило. Радослав М. Грујућ, Како се поступало са српским молбама на двору ћесара австријског последње године живота nатријарха Арсенија III Чарнојевића, Нови Сад 1906, 29-32; Славко Гавриловић, Даљско властелинство Карловачке митрополије у XVIII веку, Зборник Матице српске за друштвене науке, 46, Нови Сад 1967, 21 22.

${ }^{16}$ АСАНУК, МПА „А“ 156. и 159/1768

17 Значајно је напоменути да је поред администрирања Карловачком митрополијом владици Јовану препуштено и администрирање црквом у Ердељу, која је од смрти владике Дионисија Новаковића крајем 1767. такође била седисвакантна. Ондашњи православни верници су 6/17. фебруара 1768. молили митрополита Павла Ненадовића да им постави другог епископа, али како се његова јурисдикција није простирала на Ердељ, он је писмо 8. априла проследио Илирској дворској депутацији преко дворског агента Шерера. АСАНУК, МПА „А“ 15, 42. и 158/1768. 
институцију администратора сва писма слао вршачком дијецезану, иако њихов број није био велик, а сам је у Протоколу, који је настао касније, забележен у периоду крај октобра 1768 - почетак фебруара 1769. као привремени администратор Митрополије. ${ }^{18}$ Током децембра 1768 . и јануара 1769. комуницирао је са Илирском дворском депутацијом и Илирском комисијом у Осеку пре свега у вези са финансијским питањима, као што је враћање дугова Илирске хусарске регименте. ${ }^{19}$ Почетком фебруара у Нови Сад је стигао Јован Георгијевић, одакле је ускоро прешао у Карловце, где је конкретно радио на припреми Сабора и бринуо о свим текућим питањима. ${ }^{20}$ Током марта 1769. царски комесар, гроф Андрија Хадик, јавио је владици Георгијевићу да на Сабору не могу присуствовати посланици из Будимске дијецезе, јер су они због начина на који је предложен за епископа Дионисије Новаковић 1749. кажњени. ${ }^{21}$ у међувремену владика Јован је обавестио протопрезвитере у Архидијецези да депутате пошаљу 16. априла у Карловце. Гроф Хадик га је крајем марта обавестио да ће се доћи 24. априла, што је значило да за његов долазак мора све бити припремљено. Најављеног датума стигао је комесар, дочекан по прописаном церемонијалу, а потом је уследила провера пуномоћја депутата, чиме су почеле предсаборске радње. ${ }^{22}$

Сабор је коначно отворен 4. маја 1769. а био је један од најзначајнијих које су Срби у Хабзбуршкој монархији одржали. Његова директна последица било је доношење Првог илирског регуламента 1770, на основу информација које је комесар скупио и послао у Беч током петомесечних расправа. ${ }^{23}$ Саборски сукоби, најчешће између вође народне опозиције, темишварског дијецезана Вићентија и комесара, који, чини се, није добро схватао положај српског народа, као ни начин опхођења са епископатом, због чега је чак опоменут са Двора, били су жучнији него иначе. Још од отварања видело се да администратор рачуна на митрополијски трон, показујући се веома умереним, и стајући на страну Двора чак и против осталих епископа. Истовремено, он је био и особа са којом је као будућим митрополитом рачунао и

\footnotetext{
${ }^{18}$ Уз име Мојсија Путника је у протоколу, који је настао касније, стављен придев на латинском (са немачким завршетком -inetrimaler) и немачком (einsweilen) који има исто значење (привремени, за неко време), али се могао односити и на то да је он некада управљао као администратор Митрополијом. Међутим, вероватније је да је њему у одсуству владике Јована поново прећутно препуштена администрација, на шта упућује чињеница да се у протоколу од октобра 1768. до фебруара 1769. не помиње Јован, него само Мојсије. Вид. податке за октобар-децембар 1768. и јануар-фебруар 1769. у: АСАНУК, МПА „А“ Protocollum Exhibitorum registraturae Archiepiscopalis Carloviczensis inclitae Nationis Illyrico Rascianae de Anno 1768 usque ad Annum 1770. Numero 11.

19 АСАНУК, МПА „А“ 168 . и 171/1769.

${ }^{20}$ Између осталих издваја се једно о којем је и знатно касније расправљано - питање сахрањивања. Наиме, Илирска дворска депутација је јављала владици Георгијевићу да утиче на свештенство у вези са сахрањивањем покојника јер имају податке да се у Банату покојници држе у отвореним сандуцима и по осам дана иако је за то прописано најдуже два дана. АСАНУК, МПА „А“ 177/1769.

${ }^{21}$ АСАНУК, МПА „А“ 183/1769. Акт којим се објављује казна у: АСАНУК, МПА „А“ 544/1750.

${ }^{22}$ АСАНУК, МПА „А“

${ }^{23}$ Иако је у формалном смислу Карловачка митрополија остала седисвакантна све док у септембру није изабран за митрополита њен администратор, овде неће бити речи о периоду током којег је трајао Сабор, јер он представља засебну целину, а администрација владике Георгијевића пред скупом у којем су били сви епископи губи снагу. Такође, током самог Сабора он није био најутицајнији међу епископима и у вези са њим није било већих спорова. Активнији је постао тек непосредно пред митрополијски избор у септембру 1769.
} 
Двор, иако је народ на месту првојерарха желео да види горњокарловачког владику Данила Јакшића. На крају је ипак 7. септембра 1769. изабран администратор Јован, а уведен је у трон карловачких архиепископа и митрополита 26. септембра. ${ }^{24}$ Овим чином је завршена прва седисваканција у току које је црквом више управљао владика Мојсије Путник него новоизабрани првојерарх као администратор којег је на то место поставила Марија Терезија.

Седисваканција 1773-1774. Митрополит Јован Георгијевић није дуго био на челу Карловачке митрополије. Чини се да је своју смрт предосетио јер је 22. маја 1773. написао тестамент, тражећи између осталог да га сахране у манастиру Гргетегу. ${ }^{25}$ Већ 24. маја бачки епископ Мојсије је послао циркуларно писмо фрушкогорским манастирима у којем их обавештава да је претходног дана умро митрополит Јован, чију смрт треба да огласе сви манастири и да за сахрану пошаљу настојатеље у Карловце. Исту вест је послао епископима Карловачке митрополије, а 25. маја је тражио од Славонске генералне команде да за 29. истог месеца пошаље милицију у Карловце која би учествовала у митрополитовој сахрани. По овоме је изгледало да ће Георгијевић бити сахрањен у Карловцима, али до тога није дошло, при чему ни његова последња воља није поштована, јер је уместо у Гргетегу сахрањен у Крушедолу. ${ }^{26}$

Бачки владика је почео привремену управу Митрополијом припремом сахране јер је био најближи у тренутку Георгијевићеве смрти, али и јер му је ово била дужност на коју га је обавезивао $8 \S$ и $12 \S$ Првог регуламента. Наиме, он је био један од тројице асистената који су се старали уз митрополита о Неприкосновеном фонду и о имовини Митрополије после смрти њеног првојерарха. ${ }^{27}$ У складу са овим законом стављена је службена забрана на имовину која је морала бити пописана, а о свему је обавештавана Илирска дворска депутација. Управо на том послу су радили владика Мојсије и асистент, пуковник Јован Белгради, одмах по митрополитовој смрти. У 11 часова увече истог дана којег је митрополит умро, у Карловце је стигао изасланик из Петроварадина који је, такође, ставио забрану на митрополитову имовину. Међутим, Илирска комисија из Осека је тражила од Мојсија Путника објашњење о томе зашто није поступљено у складу са одредбама Регуламента, јер приликом стављања забране (шперта) и пописа заоставштине није било цивилног представника Темишварца, Живана Ђуричка. Администратор и пуковник Белгради су 29. јуна одговорили депутацији да због изненадне смрти митрополита и потребе да се одмах стави забрана нису могли да чекају да Ђуричко стигне из Темишвара, али да је зато присуствовао хаџи Крста Лукић, међутим, он може само присуствовати стављању забране али не и бити трећи асистент јер за то прво мора добити потврду владарке. Ово је било у складу са Регуламентом по коме

\footnotetext{
${ }^{24}$ Ђорђе Рајковић, Српски народни сабор 1769. у Карловиима, Српски летопис, 114, Нови Сад 1872, 180 185; J. Х. Швикер, Политичка историја Срба у Угарској, Нови Сад - Београд 1998, 181-200.

${ }^{25}$ Тестамент је отворен у присуству владике Мојсија Путника, пуковника Јована Белградија и народног секретара Павла Ненадовића. АСАНУК, МПА „Б“ 37/1773.

${ }^{26}$ АСАНУК, МПА „А“ 442, 444. и 449/1773.

${ }^{27}$ Уз Мојсија Путника, који је био асистент у име цркве, пуковник Јован Белгради је био у име војске, а темишварски сенатор Живан Ђуричко у име цивила. АСАНУ, 7253.
} 
је одређено да ако један асистент не може присуствовати стављању забране и пописивању оставине покојника, њега мора заменити карловачки судија или неки члан магистрата православне вере. Владика Путник је послао Илирској комисији у Осек 17. јула 1773. новосастављени Инвентар о имовини претходног митрополита. ${ }^{28}$

Владика Путник је 5. јуна 1773. обавестио Илирску дворску депутацију да је митрополит умро и да је он предузео све потребне мере у складу са Регуламентом који је прописивао и да се на погребу првојерарха од владара затражи да постави администратора, те је у том правцу и он обавестио депутацију, предлажући да одреде архиепископског и вршачког администратора, јер ова епархија није попуњена од избора 1769. Јована Георгијевића за митрополита. Није се дуго чекало на решење jep је Марија Терезија у складу са Регуламентом одредила темишварског владику Вићентија Јовановића Видака за администратора вршачке дијецезе, а Путник је крајем маја поставио раковачког архимандрита, Петра Петровића, за надзорника дворјана у седишту Митрополије и контролора имовине. Иако је фактички управљао црквом као њен администратор, потврду свог положаја добио је бачки дијецезан тек са писмом које му је послато преко Илирске комисије 24. јуна $1773 .{ }^{29}$

Почетак администрације владици Путнику је донео низ нерешених финансијских проблема. ${ }^{30}$ Поново је покренуто питање заоставштине покојног арадског епископа Синесија Живановића чије решавање је остављено тадашњем епископу овог владичанства, Пахомију Кнежевићу. ${ }^{31}$ Јавила су се и потраживања дворског ратног саветника Шојермана и штампара Курцбека, првог од 2.000 форинти, другог 440, о чему је Илирска комисија тражила обавештење од митрополијског администратора, а он се правдао да о томе ништа не зна и да тек треба да проучи захтеве ове двојице на основу архиве митрополита Јована. ${ }^{32}$ Наметало се и питање заоставштине покојног митрополита, као вршачког владике, jep је она требало да припадне Митрополији, после давања подушја епископу и евентуалног враћања дугова. У овом случају, пошто су подушја и дугови враћани из оставине митрополита Јована као првојерарха, а не вршачког владике, све је морало припасти Митрополији на следећи начин: половина би била препуштена Школском фонду, а друга половина се делила на два дела, од којих је један ишао у Неприкосновени фонд, а другим је управљао митрополит, али искључиво за хуманитарне потребе. Како у овом тренутку није било митрополита, ни овом четвртином заоставштине се није могло слободно располагати. ${ }^{33}$ Зато је више пута тражено да имовина која се налази у Вршачко-карансебешкој епископији преко

\footnotetext{
${ }^{28}$ АСАНУ, 7253; АСАНУК, МПА „А“ 448, 453, 455, 461, 462, 468, 469, 473. и 510/1773.

${ }^{29}$ АСАНУ, 7253; АСАНУК, МПА „Б“ 68/1773, „А““ 450, 460. и 464/1773. Пре владике Видака, одмах после смрти митрополита, поставио је бачки владика за привременог администратора ове дијецезе вршачког протопопа, док не буде донето другачије решење. АСАНУК, МПА „А“ 447/1773.

${ }^{30}$ Између осталог, од њега је Илирска комисија тражила да реши питање дуга сликара Дворске коморе Франца Цумпе којем је за два портрета, мали и велики, дуговано још 14 дуката. АСАНУК, МПА „А“ 1/1774.

${ }^{31}$ АСАНУК, МПА ,А“ 474/1773.

${ }^{32}$ АСАНУК, МПА „А“ 471. и 475/1773.

33 АСАНУ, 7253; Славко Стеф. Видаковић, Постанак и развитак срп. народно-ирквених фондова и фундација у Сремским Карловцима (од 10. авг. 1749. до 31. дец. 1922.), Нови Сад 1922, 15-17.
} 
вршачког и карансебешког протопрезвитера буде пописана и оно што по Регуламенту припада фондовима, буде послато у Карловце. Администратор је опомињао и будимског владику да по наредби из Беча и Регуламенту одређени новац и интерес, који су укупно износили 7.520 форинти, у најкраћем року пошаље у Карловце. Бринуо је и да приватна лица, која су узела новац под интерес из Неприкосновеног фонда, врате и главницу и камату. Такође, Илирска дворска депутација је јавила владици Видаку, као епископу у обе банатске епархије, да еквивалент десетка за Банат, од 1. јануара до 23. маја, као дана смрти митрополита, мора бити припојен његовој имовини. ${ }^{34}$

Поред финансијских питања у време ове седисваканције дошло је до покушаја друге редукције заповедних празника, коју је по налогу Двора извршио Атанасије Димитријевић (Деметровић) Секереш, али је Мојсије Путник сматрао да у вези са овим питањем не може одлучити он него Сабор. У том циљу је и одговорио барону Францу фон Колеру, председнику Илирске дворске депутације, на писмо које је овај, поводом истог питања, упутио митрополиту још у марту $1773 .{ }^{35}$ Ова редукција је била знатно радикалнија од оне коју је 1769. и 1770. извршио покојни митрополит, јер иако је број заповедних празника које је требало укинути био мањи него први пут, међу њима су се нашли сви српски светитељи осим Светог Саве, што је изазвало негодовање епископата и народа. ${ }^{36}$

Међу обавезама администратора била је и припрема изборног Сабора, што je, такође, било у вези са финансијским питањем. Трошак Сабора није смео да пређе суму од 1.475. форинти које су узимане из заоставштине претходног митрополита и/или из прихода који су скупљени у време седисваканције. Овде, међутим, нису улазиле дневнице посланика, које су уз надокнаду за пут исплаћиване од новца који је разрезан на сва православна домаћинства у Карловачкој митрополији. ${ }^{37}$ У таквој ситуацији администратор није сам могао да донесе све одлуке па су се у Карловцима средином октобра са Путником састали темишварски владика Видак и пакрачки Атанасије Живковић, али о њиховим договорима у сачуваним документима нема пуно трага, сем да су одлучили да заједно траже од владарке сазивање Сабора. ${ }^{38}$ Владарка је преко Илирске дворске депутације 17. децембра 1773. издала акт којим се дозвољава његово одржавање, наређујући да о томе администратор обавести све епископе, а они своје вернике. За комесара је одређен барон генерал фелдмаршаллојтнант Јохан Андреас Матезен. ${ }^{39}$

\footnotetext{
${ }^{34}$ АСАНУК, МПА „А“ 456, 474, 536, 538, 545. и 547/1773, 24/1774.

${ }^{35}$ АСАНУК, МПА „А“ 404 . и 493/1773.

${ }^{36}$ Мита Костић, Гроф Колер као културно-просветни реформатор код Срба у Угарској у ХVIII веку, Загреб 2011, 111-114.

${ }_{37}$ Ова сума се по $15 \S$ Регуламента односила само на сабор који би бирао наследника митрополита Јована, јер је прописано да од те суме 300 форинти буде утрошено за комесаров балдахин, који би се користио и убудуће приликом сабора, тј. ова сума је морала за наредне саборе бити измењена и укупно би износила 1.175 форинти. Међутим, по Деклараторији (1779), средства су повећана на 2.000 форинти, од чега је сама парада приликом дочека комесара и инсталације митрополита износила 500 форинти. АСАНУ, 7253 Дејан Микавица, Владан Гавриловић, Горан Васин, Знаменита документа за историју српског народа 1538-1918, Нови Сад 2007, 100-101.

${ }^{38}$ АСАНУК, МПА „А“ 530. и 534/1773.

39 Барон Матезен и владика Мојсије Путник су још пре његовог постављања за комесара имали неке
} 
Од краја јануара 1774. Путник је чешће комуницирао са комесаром Матезеном, ${ }^{40}$ интересујући се када ће доћи у Карловце. Како је комесар морао да обави још пут у Беч пре Сабора, о томе је 16. јануара 1774. обавестио Путника. Администратор је крајем јануара 1774. послао писма свим епископима да са народом изаберу посланике, из сваког сталежа по 25, и да буду спремни да после Ускрса дођу на Сабор. Тек 5. априла 1774. послао је писма свим епископима да ће комесар стићи 13. маја и да они до тада треба да буду у Карловцима. Комесар је намеравао да Сабор буде отворен 13. маја, али да сви посланици морају стићи два дана раније, док би 13. уследио церемонијални део и то онако како је он изгледао на Сабору 1769. Нешто раније обавестио је настојатеље сремских манастира да се скупе у једном од њих и ту изаберу свог представника. Пре отварања Сабора послао је комесар у Карловце саветника Рајхенбаха са задатком да прегледа рачуне, нарочито оне за које се тражило додатно објашњење, а са многима није био задовољан не само тада него и после Сабора. ${ }^{41}$

Пре него што је Сабор почео да ради, посланици су од владарке тражили дозволу да се прошири митрополијски двор јер нарасле потребе администрације захтевају нове просторије. Ово је питање поново покренуто и на самом Сабору, а упућена су и два конкретна предлога, први да се за проширење двора распише порез на народ, што је постојећи Регуламент забрањивао, и други, да се за то искористе средства која су остала после враћања дугова Илирске хусарске регименте, а износила су 13.615 форинти. Од отварања Сабора до митрополијског избора и даље је кључна личност којој се комесар обраћао био владика Путник, а главна тема су била финансијска питања. Најкрупније се односило на Арадску епархију у вези са заоставштином Синесија Живановића из које је тадашњи арадски владика Пахомије за домаћинство потрошио 2.927 форинти, због чега је од њега тражено да положи рачуне како их је утрошио. Уз ово још увек су постојала значајна средства (преко 3.000 форинти) која нису исплаћена посланицима на Сабору 1769. Расправа о финансијама настављена је и касније на Сабору и Синоду, али је пре тога уследио избор митрополита. Посланици су већ 10. јуна 1774. јавили Марији Терезији да је за митрополита изабран темишварски владика Видак, чију су потврду молили. Његовим избором престала је седисваканција, и одмах му је препуштено решавање финансијских и других питања. Владика Путник се захвалио Двору што је у њега имао толико поверења да му је препустио администрацију удове Митрополије и припрему Сабора. Нови митрополит је и формално уведен у дужност по полагању заклетве у цркви 16. јуна 1774. У даљем раду Сабора доминирале су жалбе на Први регуламент, а комуникација са комесаром ради решавања разних проблема настављена је наредних скоро годину дана, у току које је и Путник захтевао да му се

контакте. АСАНУК, МПА „А“ 485, 505. и 550/1773.

40 У исто време стигла су у Карловце решења која је Путник морао да пошаље арадском епископу Пахомију Кнежевићу, по коме му се забрањује купљење димнице и других пореза, док скупљено мора вратити, као и да се одбија његов захтев да на Бабунском салашу, поседу арадских епископа, отвори крчму са правом точења ракије и вина. АСАНУК, МПА „Б“ 69. и 70/1774.

${ }^{41}$ АСАНУК, МПА „А“ 8-10, 32, 33, 35, 48, 54. и 64/1774; АСАНУК, МПА „Б“ 11, 114. и 123/1774. 
исплате средства на која је имао право као администратор. ${ }^{42}$

Седисваканција 1780-1781. Митрополит Вићентије Јовановић Видак преминуо је изненада током боравка на Даљском властелинству, 18/29. фебруара 1780. И овог пута је бачки епископ, у то време Арсеније Радивојевић, био најближи, те је одмах обавестио остале владике и Двор о смрти првојерарха. ${ }^{43}$ Већ 12. марта изашло је решење Марије Терезије, преко Угарске дворске канцеларије и Дворског ратног већа, да је за администратора постављен, у то време темишварски епископ, Мојсије Путник. ${ }^{44}$ Овим је почела његова трећа управа удовом Митрополијом, а већ крајем марта стигао је у Карловце. Темишварски дијецезан је био најстарији по времену хиротоније од свих владика Митрополије и свакако у ранијем периоду у управљању црквом током седисваканције показао доста успеха и имао највише искуства. Ипак, Двор овог пута није имао поверења ни у њега ни у било ког Србина који би пописао оставину покојног првојерарха, него је 28. марта послао тројицу официра да то учине. Били су то мајор у Петроварадинском пуку барон Фон Тајлирс, аудитор у Шајкашком батаљону натпоручник Фон Орландини и судски писар Ђиловски (Gÿlovszky). Они су 20. априла саставили инвентар наплаћених и ненаплаћених дуговања митрополита Видака (оно што је њему дуговано), али је ово био тек почетак замршених финансијских потраживања. За почетак, бринући за економију митрополијског двора, владика Путник је овластио да њиме управљају шишатовачки архимандрит Гедеон Никетић и раковачки Јосиф Јовановић Шакабента. ${ }^{45}$

Као и током претходних администрација, финансијска питања су била од изузетне важности. Администратор је почетком јуна 1780. тражио информацију од Угарске дворске канцеларије зашто му се не исплаћује у кварталима приход који митрополити добијају на име десетка из Славонске и Темишварске камералне касе. Такође, молио је владарку за дозволу да од добра Даљ ужива митрополијске приходе и да у том циљу донесе што брже решење. Славонска генерална команда из Осека, која је играла исту улогу као Илирска комисија током претходне администрације, тражила је од владике Путника, 20. јуна, да јој јави колико износе трошкови администрирања. Иста инстанца му је послала и обрачуне митрополијских прихода на Даљском властелинству, које је сачинио Трифун Јовановић Видак, брат покојног првојерарха. Угарска дворска канцеларија је сматрала да се и током седисваканције администратору може у ратама предавати аренда од овог поседа. О овоме се неколико дана касније консултовао са управником и арендатором Даљског властелинства Павлом Ненадовићем и направљена је рачуница колико му припада од десетка, док је Славонска генерална команда одговарала да му се у месечним ратама дају приходи од добра Даљ, међутим, овај новац он није смео да троши јер је

${ }^{42}$ АСАНУК, МПА „А“ 11, 12, 70-73, 76, 77, 79, 84. и 86/1774; АСАНУК, МПА „Б“ 3, 9, 72. и 73/1774.

${ }^{43}$ АСАНУК, МПА „А“ 372 . и 374/1780.

${ }^{44}$ На Архијерејском синоду који је радио после Сабора 1774. затражено је од Марије Терезије да буду попуњене седисвакантне епископије, али и да бачки владика пређе на темишварску катедру. Са другим захтевима прихватила је и овај 10. новембра 1774. те је владика Мојсије могао бити инсталиран у Темишвару, што је уследило почетком 1775. АСАНУК, МПА „А“ 99, 139, 254. и 287/1774; АСАНУК, МПА „Б“ 83/1774

${ }^{45}$ АСАНУК, МПА „А“ 375, 380, 383. и 385/1780. 
припадао Неприкосновеном фонду. Бивши саборски комесар Матезен, командант у Славонији и Срему, јавио је у септембру 1780. да код дворског агента постоји облигација од 8.000 форинти са интересом од 960 форинти, које ће бити враћени Неприкосновеном фонду. ${ }^{46}$

Током ове седисваканције морао је Путник да решава и друга питања. Уместо двојице асистената, бачког владике Арсенија Радивојевића ${ }^{47}$ и шајкашког пуковника Станисављевића, Дворско ратно веће је тражило нове. У име цркве је требало да буде постављен вршачки епископ Вићентије Поповић, војске шајкашки капетан Јован Станисављевић, а у име Провинцијала Марко Ђурковић пл. од Сервицки. $^{48}$ Озбиљнији проблем од овога била су дешавања у делу Пакрачког владичанства. Владика Арсеније Живковић жалио се администратору на јак унијатски притисак у његовој епархији, пре свега у Вараждинском генералату. Епископ га је молио да разне народне тужбе пошаље у Беч, како би се прекинуло са опасном праксом прогањања српског језика и затварања српских школа. Пакрачки дијецезан се нарочито жалио на ђаковачког бискупа Матију Фрању Кртицу, који је на бискупском поседу прогањао Србе. У октобру 1780. администратор је на захтев темишварског жупана Фрање Естерхазија циркуларним писмом смиривао свештенство и народ у својој епархији како се не би противили новим политичким дешавањима, пре свега у погледу присаједињења Баната Угарској. Нарочито је настојао да свештенство одвоји од било каквих политичких радњи. ${ }^{49}$

Почетком јуна у Карловцима су се састали виђенији Срби који су у име народа и цркве упутили захтев Угарској канцеларији, а преко ње и Марији Терезији, да дозволи сазивање Сабора за избор архиепископа и одреди комесара који ће му присуствовати. У августу је царица одговорила дозвољавајући Сабор, али и сматрајући да са њим не треба журити. Ово је био разлог да се са озбиљнијим разговорима, вођеним највише са председником Угарске дворске канцеларије Фрањом Естерхазијем, а у вези са Сабором, почело тек крајем године. Иако је било неких спорних питања - пре свега у вези са насељима из којих су посланици на Сабору 1774. били као провинцијалисти, а сада су ова насеља у Војној граници најважнија су била поново она финансијске природе. Коначно је, преко Угарске дворске канцеларије, цар Јозеф II решењем од 23. марта 1781. дозволио да буде одржан изборни Сабор у Карловцима, за који је као свог комесара одредио грофа Антона Јанковића од Дарувара. Донето је и решење да становници војних

\footnotetext{
${ }^{46}$ АСАНУК, МПА „А“ 394, 406, 410, 420, 429, 435. и 438/1780; АСАНУК, МПА „Б“ 30/1780.

${ }^{47}$ Владика Радивојевић је био замењен и због менталног здравља. Наиме, против њега је покренута парница за содомију, због које је доживео нервни слом. Услед овога, морао је, по захтеву председника Угарске дворске канцеларије, грофа Естерхазија, бити затворен у један манастир, где је за његово издржавање одређено 200 форинти. Администрирање Бачком епархијом је препуштено будимском владици Софронију Кириловићу, а Радивојевић је упућен у Бездин, под надзор манастирског архимандрита Павла Авакумовића. Касније је Радивојевић повео контрапарницу како би се оправдао, а на својој страни је имао најугледније грађане новосадске. Ипак, решење спора није дочекао јер је умро октобра 1783. Његов адвокат је наставио парницу доказујући невиност покојног епископа. АСАНУК, МПА „Б“ 3/1780; „А“ 479, 483. и 497/1781; Ђорђе Рајковић, Владика Арсеније Радивојевић и његово страдање, Летопис Матице српске, 127, Нови Сад 1881, 45-57.

${ }_{48}$ АСАНУК, МПА „А“ 453/1780. У овом звању су потврђени 10. јула 1781. АСАНУК, МПА „А“ 540/1781.

${ }^{49}$ АСАНУК, МПА „А“ 436/1780; АСАНУК, МПА „Б“ 16, 17, 59. и 61/1780.
} 
комунитета (Земуна и Карловаца) на Сабору буду представници који се рачунају међу војна лица. Одмах су обавештени настојници сремских манастира да се састану одједном и изаберу своје посланике. Комесар се из Весприма јавио 7. априла администратору са предлогом да Сабор буде отворен 11. или 12. јуна по новом календару. Од Сабора се није очекивало ништа више него да само буде изабран митрополит, о чему је комесар посебно обавестио администратора. Владика Путник је 31. маја 1781. јавио да саборски трошак (са посланичким платама) износи 8.000 форинти. У вези са сазивањем Сабора и бирањем посланика појавиле су се новине у односу на претходни, због којих је дошло до жалби. Тако се Сомборска српска општина жалила да им комесар не дозвољава приступ Сабору, иако су га имали на прошлом, а да из целе средине иде само један суботички посланик, те су питали администратора да ли могу рачунати на његову заштиту ако дођу на Сабор. ${ }^{50}$

Током ове администрације решавани су и проблеми који су се јавили на Даљском властелинству у вези са приходима. Они нису настали тада, него су старији и у њиховој суштини лежи сукоб двојице митрополијских рођака, Павла Ненадовића (синовац митрополита Павла Ненадовића) и Трифуна Јовановића Видака, јер су обојица настојала да од њега стекну што већу материјалну корист. Видак је био нарочито угрожен када је његов брат пристао да Ненадовић буде не само управник него и арендатор властелинства. Митрополит Видак је брзо увидео да је направио грешку на штету брата, али је било касно, и од 1778. јавио се низ проблема. ${ }^{51}$ Сам покојни митрополит је имао знатна дуговања, а новац који је узео из Школског $(18.826 \text { форинти) })^{52}$ и Неприкосновеног фонда (2.453) је морао бити враћен. На крају је Школски фонд током Видакове управе увећан за свега мало више од 2.000 форинти. ${ }^{53}$

Сабор је почео са радом 1. јула и већ трећег дана његовог рада упућено је писмо владару да је за митрополита изабран темишварски епископ и дотадашњи администратор Мојсије Путник, молећи да га потврди у том звању, како би могао да буде уведен у њега. Путниковим избором престала је седисваканција, а он је после дуге епископске службе (од 1757), три администрирања Митрополијом и удовим епархијама постао првојерарх српске цркве у Хабзбуршкој монархији. Цар га је потврдио и у новембру му издао конфирмациону диплому преко Угарске дворске

\footnotetext{
${ }^{50}$ АСАНУК, МПА „А“ 398,431 . и 466/1780; 468, 488, 489, 492, 495, 510, 518. и 609/1781; АСАНУК, МПА „Б“ 12 . и 16/1781

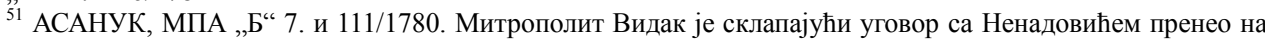
њега сва своја овлашћења као земљишног господара и право на убирање свих прихода. Заузврат он је митрополиту годишње плаћао 7.500 форинти у четири рате. Видак није имао никаквих трошкова на спахилуку, већ је све морао да надокнади Ненадовић, што је изискивало знатне суме новца, због којих је арендатор повремено прекорачивао права одређена уговором и постојећим урбаром. Током сукоба са Трифуном Јовановићем Видаком, још за живота митрополита Вићентија, закључено је да је митрополит оштећен, а цифра се кретала између 4.000 и 19.000 форинти. У цео спор се после митрополитове смрти умешао Двор, али је Ненадовић докраја уговором одређеног периода остао арендатор и управник добра (до 1784). С. Гавриловић, Даљско властелинство..., 49-55.

${ }^{52}$ Митрополит је узео из Школског фонда прво 11.000 а потом 7.000 форинти, први зајам му је дат без интереса, а за други је плаћао интерес $5 \%$, с тим да главницу отплаћује годишње по 2.000 форинти. АСАНУК, МПА „Б“ 98/1780.

${ }^{53}$ АСАНУК, МПА „Б“ 13. и 14/1780.
} 
канцеларије, за коју је платио таксу Дворском ратном већу и поменутој канцеларији. ${ }^{54}$ На челу Карловачке митрополије остао је до смрти 28. јуна 1790.

Током постојања Карловачке митрополије, као црквене организације Срба у Хабзбуршкој монархији, њен трон је био упражњен двадесет пута, од чега је само између 1706. и 1790. био празан више од осам година. Седисваканција, како је називан период током којег није било првојерарха на челу цркве, почињала је од смрти једног и трајала до избора новог митрополита. Како је црква морала да настави свој живот и у овом, нередовном стању, постављан је на њено чело, као администратор, привремени управник, један од епископа. Током периода значајних државних реформи у Хабзбуршкој монархији, које нису мимоишле ни Србе, Карловачка митрополија је била седисваканта три пута $(1768-1769,1773-1774$. и 1780-1781), у укупном трајању од три и по године. У време ове три седисваканције најзначајнија личност је био епископ Мојсије Путник, најпре као бачки, а потом темишварски владика. Он је био администратор два пута по жељи Двора, а једном у складу са народном вољом, када је смењен са тог положаја, јер није поштовано владарско регално право по којем само он поставља администратора удове цркве. Ипак, Мојсије Путник није био особа против које је Двор нешто имао, напротив, последње две администрације и коначно његов избор за митрополита 1781. су управо потврдили да је Двор имао доста поверења у њега, али да је свој принцип и право морао да оствари без обзира на могуће последице. Делатност владике Путника, као администратора, одвијала се у два правца, првом, као рад на припремању наредног Сабора, и другом, као рад на решавању насталих финансијских проблема. У оба случаја, сем током прве администрације, његово деловање је било у оквирима које је прописивао Први илирски регуламент из 1770 , односно Деклараторија из 1779. Држећи се ових аката, администратор је организовао Сабор, преко владика избор посланика, дочек и смештај царског комесара и водио све радње до избора митрополита. Уз то, настојао је да дође до што већих финансијских средстава, јер су она током седисваканције била мања него у редовном стању, али на овом пољу није имао успеха. Решавао је и све проблеме који су се у то време јавили, као покушај друге редукције заповедних празника, новонастали унијатски притисци, прогањање ћирилице и затварање српских вероисповедних школа у Вараждинском генералату, политичка превирања међу народом, а нарочито свештенством у Банату после објаве да ће бити инкорпориран у Угарску, сукоби на Даљском властелинству итд. Посматрајући у целини Путниково управљање Карловачком митрополијом у време три седисваканције, уочава се да је он цркву водио веома успешно, да није излазио из оквира који је наметала постојећа законодавна регулатива, сем у безуспешном настојању, да дође до већих финансијских средстава. Овакав став додатно је утицао на то да он постане persona grata за Двор и коначно да се попне на митрополијски трон, са којег је водио цркву наредних девет година.

${ }^{54}$ АСАНУК, МПА „А“ 527, 613, 623. и 624/1781. 


\title{
EPISCOPE MOJSIJE PUTNIK'S ADMINISTRATION OF THE METROPOLITANATE OF KARLOWITZ
}

\begin{abstract}
Summary
The Metropolitanate of Karlowitz as a Serbian ecclesiastical organisation within the Habsburg Monarchy played an important role in the history of Serbs. From 1708 to 1913 there was a succession of nineteen metropolitans as its head. In the time between the death of one and the election of a new metropolitan, the so-called sede vacante, the church was ruled by one of the episcopes as its administrator. Mojsije Putnik, first the episcope of Bačka, and then of Timisoara, held this position three times (1768-1769, 1773-1774 and 1780-1781), though he was replaced during his first mandate. His work as an administrator was solely within what the law (First Illyrian Regulament and Declaratorium) proscribed, while only in the financial matters he strived to acquire significant assets, but without success. Successful church management, without confronting the Court, resulted in his becoming a desirable candidate for the metropolitan, both in the eyes of the people and the Court, in the Synod of 1781. This secured him the position of the hierarch of the Serbian church in the Habsburg Monarchy, which he held until his death in 1790 .
\end{abstract}

Keywords: Metropolitanate of Karlowitz, sede vacante, administration, synod, Jovan Georgijević, Vićentije Jovanović Vidak, Mojsije Putnik. 